\title{
Identification of Barrier Factors and Potential Solutions to SMEs Development among Jordanian Manufacturing Sector
}

\author{
Khalil Al-Hyari ${ }^{1}$ \\ ${ }^{1}$ Faculty of Business, Al-Balqa Applied University, Jordan \\ Correspondence: Khalil Al-Hyari, Faculty of Business, Al-Balqa Applied University, Jordan. E-mail: \\ kalhyari@bau.edu.jo orkhyari77@yahoo.com
}

Received: August 26, 2013

Accepted: September 29, 2013

Online Published: November 20, 2013

doi:10.5539/ijbm.v8n24p132

URL: http://dx.doi.org/10.5539/ijbm.v8n24p132

\begin{abstract}
The purpose of this paper is to investigate the factors that hinder the growth and survival of SMEs in Jordan. The methodology adopted in this research is critical literature reviews, quantitative data collection through questionnaires to 241 SMEs 'owners and managers located in selected cities in Jordan. The results of the study reveal that the most common constraints hindering SMEs growth and survival in Jordan are: lack of financial support; competition barriers; lack of qualified human resources; and rigid business rules and regulations. Most SMEs agreed that government should develop program that is strongly required as a strategic move to emerge the economy and dedicate more efforts to eliminate SMEs barriers, like encourage the financial institutes and banks to provide suitable credit facilities to this sector. Legal infrastructure such as privacy law, e-signature and knowledge acquisition law, facilitate SME with technology through soft loan to buy supporting technology for their business, and many supporting program needed by SMEs. The significance of this study stems from the fact that very few studies have explored the issue of factors constraining the growth and survival of SMEs in Jordan. Also, it offers guidance for future research in a field of research that is still in its infancy.
\end{abstract}

Keywords: barriers factors, potential solutions, SMEs development

\section{Introduction}

Irrespective of the stage of economic development, small and medium enterprises (SMEs) constitute and continue to be a main source of growth of a nation (Dasanayaka et al., 2011; Hyz, 2011; Hessels \& Parker, 2013). Given the importance of SMEs in any economy, it is no surprise that almost all the countries in the world place a special emphasis on supporting and strengthening their SMEs through a variety of support institutions and programmes. The development of SMEs has long been regarded as crucial for the achievement of broader development objectives, including, economic development, and social stability through the development of the middle class, creation of a significant number of new jobs (Okpara, 2011; Zaied, 2012; Gunerergin et al., 2012; Irjayanti \& Azis, 2012).

SMEs involvement is a serious commitment taken by Jordanian's government to develop this sector as an important foundation of Jordanian economies. However, a large number of SMEs in Jordan are struggling to survive in today's competitive environment, since most SMEs are faced with a number of barriers in their search for competitiveness and sustainability. To remove these barriers, the government should understand what the real barriers that will be faced by the SMEs are, in order to decide the successful way for helping SMEs to develop potential solutions to SMEs development.

The present study ultimate aim is to fill a gap in the literature, especially in developing countries, by explicitly focusing on the factors constraining the growth and survival of SMEs in Jordan. Recognizing the barriers facing SMEs development in Jordan which is a critical first step in managing and avoiding the massive failure of this crucial sector in Jordan has prompted the author to investigate this topic which is important in terms of the growth and survival of SMEs in global markets.

\section{Literture Review}

\subsection{SMEs Barriers}

An extensive literature review was the first step to identify and describe key barriers for SMEs development. Table 1 describes the various potential barriers faced by SMEs, especially in developing countries such as 
Jordan. Previous research and surveys reveal that the main barriers faced by SMEs include information barriers, functional barriers, finance related issues, human resource problems, technological issues, marketing barriers, infrastructure and external environment barriers, and problems regarding support provided from the government and business development service. From various sources, the author collected all indicators that have been studied by many researchers about the SME sector in developed and developing countries includes Jordan. In result, there are more than 15 factors that became barriers of SME development.

According to Dasanayaka et al., (2011) and Trianni and Cagno (2012), information barriers are related to SMEs' accessibility to the information needed while expanding the business. Lacks of information about market opportunities, changes in technology is viewed as other barriers to innovation (Kamalian et al., 2011). Information about a firm's external environment, such as market opportunities, changes in technology, and government policy help makes the firm more competitive (Guijarro et al., 2009).

Some literatures have recognized that SMEs in developing countries have a slower adoption rate of e-business compared to other developed countries, which is caused by environmental, managerial and organizational constraint that made developing countries encounter greater risks than developed countries (Janita \& Chong, 2013). Several studies were also abounding with new barriers on e-commerce adoption in SMEs in developing countries such as absence of legal and regulatory systems, cost too high and E-commerce infrastructure, lack of financial resources, and low bank account and credit card penetration (Zaied, 2012). Also, Medarova et al., (2012) recommend that an organization should evaluate the actual need to implement the e-learning program to increase performance and cost efficiency.

A brief review according to Okpara and Kabongo (2009) and Okpara, (2011) indicated that issues such as lack of management experience, and lack of infrastructure are major obstacles to small business development in Africa, most owners do not have management experience and adequate training and skills to operate a business. Therefore, a lack of management training and experience has negative consequences and has led to the collapse of many businesses.

Table 1. Describes the various potential barriers faced by SMEs

\begin{tabular}{ll}
\hline Potential Barriers & Reference \\
\hline E-Learning implementation & Zaied, 2012; Medarova et al., 2012; Janita and Chong, 2013 \\
Lack of information technology & Xie et al., 2010; Dasanayaka et al., 2011; Rhaiem, 2012; Trianni and Cagno, 2012 \\
High cost of financing & Guijarro et al., 2009; Kamalian et al., 2011; Dasanayaka et al., 2011; Hyz, 2011; \\
& Rhaiem, 2012; Irjayanti and Azis, 2012 \\
Lack of HR/Personnel training & Quader, 2008; Saini and Budhwar, 2008; Guijarro et al., 2009; Okpara and Kabongo, \\
& 2009; Dasanayaka et al., 2011; Kamalian et al., 2011; Rhaiem, 2012 \\
Competition difficulties & Okpara and Kabongo, 2009; Dasanayaka et al., 2011; Okpara, 2011; Irjayanti and Azis, \\
& 2012; Bourletidis, 2013 \\
Product/technology barriers & Dasanayaka et al., 2011 \\
Rigid business rules and regulations & Dasanayaka et al., 2011; Feldens et al., 2012 \\
Lack of infrastructure & Okpara and Kabongo, 2009; Mutalemwa, 2009; Dasanayaka et al., 2011 \\
Product quality issues & Moy and Luk, 2003; Dasanayaka et al., 2011; Okpara, 2011 \\
Low access to credit facilities & Krasiqi, 2007; Okpara and Kabongo, 2009; Irwin and Scott, 2010; Dasanayaka et al., \\
& 2011 \\
Geographical location & Dasanayaka et al., 2011; Okpara, 2011; Bourletidis, 2013 \\
Inappropriate marketing strategy & Moy and Luk, 2003; Dasanayaka et al., 2011; Siaw and Rani, 2012 \\
Corruption & Okpara, 2011; Wieneke and Gries, 2011 \\
Lack of management experience & Okpara, 2011; Irjayanti and Azis, 2012; Hessels and Parker, 2013 \\
Lack of government support & Moy and Luk, 2003; Peci et al., 2012; Siaw and Rani, 2012 \\
\hline
\end{tabular}

The lack of skilled personnel holds down the tendency of the firm for developing the innovation process (Kamalian et al., 2011). Guijarro et al., (2009) concluded that SMEs weak management commitment, which can be a signal that the organizational culture does not support innovation, has been cited as one of the more significant barriers to innovation among SMEs.

According to Saini and Budhwar, (2008) and Hessels and Parker (2013), most SMEs do not have any system of training and there is a lack of formalization in the management of people issues in SMEs. According to Quader 
(2008: 158), "establishing a small business with one or two employees will require quite different skills to those needed to manage a larger firm, with higher numbers of employees which requires the existence of complex reporting procedures together with the ability to manage by impersonalized monitoring systems".

Access to finance is a crucial determinant in all countries because it affects both creation of new firms and expansion of existing ones (Krasiqi, 2007). Commercial banks, which are the main source of finance, are unwilling to provide loans to small firms and have never really liked small business customers, since these firms are often incapable to guarantee enough collateral and owing to the high level of uncertainty surrounding SMEs (Mutalemwa, 2009; Irwin \& Scott, 2010; Okpara, 2011; Hyz, 2011). The high cost of capital is another burden in terms of SME financing. The study conducted by Krasiqi, (2007) provides evidence from Slovenia and shows that entrepreneurs ranked the high cost of finance and means of insurance of credit repayment as main barriers for SMEs development.

The information problems and lack of collateral that often characterize international investment, the home bias of financiers and the capital gearing method used by banks to evaluate small firms' foreign projects give rise to financial constraints which lead to high rejection rate of credit applications for SMEs (Maeseneire and Claeys, 2012; Tesfom \& Lutz, 2008). According to Hyz, (2011) the difficulties that Greek SMEs encounter when trying to access financing can be owing to a regulatory rigidities or gaps in the legal framework, lack of information on both the bank's and SME's side. According to Ajlouni (2006), access to finance is one of certain common problems facing all SMEs in Jordan. This can be observed in the firms' need for funds to start-up and grow. The paper mentions another problem of gaining access to finance owing to the owner managers' of SMEs attitude towards the sources of finance available to them and their lack of financial and accounting knowledge.

Marketing is the process of planning and executing the conception, pricing, promotion and distribution of ideas, goods, and services to create exchanges that satisfy individual and organisational objectives (Simpson et al., 2006). Saixing et al. (2009) found that marketing capability of firms plays the most important role in improving performance of firms. Research by Moy and Luk, (2003) of understanding barriers to SME growth in Hong Kong provided a wider range of barriers: inadequate marketing knowledge, poor product performance, and inadequate awareness of competition pressure. According to Bourletidis, (2013) SMEs in manufacturing sector have an obvious disadvantage, compared with larger enterprises, due to their limited capacity to withstand price increases and their weaker position for accessing materials.

Good product quality and design as well as good product marketing helps increase success (Tesfom \& Lutz, 2006). The smart manager ought to take advantage of quality standards to improve quality in the organisation and to create a competitive advantage (Leonidou, 2004). According to Dasanayaka et al., (2011), infrastructure issues refer to sub-sections of roads and transport facilities, electricity facilities, communication, and location issues have been cited as a barrier for SMEs development. Bad promotion becomes one of the reasons why Indonesia is defeated by another brand of other countries (Irjayanti \& Azis, 2012).

The firm's external environment includes a variety of influences, such as global competition, government policy, and economic uncertainty (Guijarro et al., 2009). Kamalian et al., (2011) found that the obstacles that were external to the firm are clearly more important than internal ones, perhaps because most internal issues can be resolved by a firm that is committed to its innovation activity. Regarding to Dasanayaka et al., (2011), business rules and regulations refer to information on how the operation of the business gets impacted by regulations. Enterprises in Malaysia are characterized by many challenges and problems such as marketing, government regulations, production, management practices and other local issues (Siaw \& Rani, 2012). Peci et al., (2012) found that informal activities caused by low levels of qualified and ethics of officials in respective institutions, as well as poor enforcement of rules, have important impact on increasing transaction costs, which in tum represents a main barrier to the further development of SMEs.

A number of foreign markets are overwhelmed by political instability owing to inflationary trends, a high degree of corruption, great foreign debt, military control, and clash with neighbours (Leonidou, 2004; Rasheed, 2005). Tesfom \& Lutz (2008) found that political risks, for instance the imposition of restrictions by the government of the customer or any government action that may block or delay the transfer of payment by the buyer, risks emanating from civil war and civil disturbance in the buyer's country, and unexpected additional transport costs influence the efficiency of the export success in developing countries.

Feldens et al., (2012) found that the difficulties concerning legal barriers, costs and availability of capital, the difficulty to find technical and management qualified professionals to engage in new and uncertain businesses are the main barriers for production innovation in small and medium technology-based firms in Brazil. Al-Hyari study (2011) found that SMEs in Jordan pointed a fact that politics is a significant barrier, especially in export 
activities.

In general, today's business environment is characterized by corruption and unfair competition that often jointly hinder SME growth. Additionally, corruption as a socioeconomic phenomenon is one of the main obstacles in transition, causing harm to the economy and society (Krasiqi, 2007). Okpara, (2011) found that the most common constraints hindering small business growth and survival in Nigeria are: corruption, and low demand for product and services. According to Wieneke and Gries, (2011) the two prominent problems for small and medium enterprises, corruption and finance, are mutually reinforcing.

SME is an important sector in Jordan as a base for making economy policy target, but the government still pays small awareness to the barriers that are faced by SMEs, for instance less supportive policies and regulations (Al-Hyari et al., 2011). Jordan's accessions to the WTO and the general liberalisation facilitated by the general agreement on tariffs and trade (GATT) have contributed to the structural shift in the economy in recent years and brought considerable strong competition. Consequently, the government should critically consider SME promotion and develop program that is powerfully required as a strategic move to enhance the Jordanian economy.

\subsection{SME in Jordan}

Small and medium enterprises are considered as the backbone of the Jordanian economy. SMEs account for about $98 \%$ of all industrial establishments, and $80 \%$ of country's employment (DOS, 2011). A large number of employees are being absorbed into the manufacturing SME sector in the country each year. This means that the manufacturing sector in Jordan is creating a lot of jobs compared with other sectors. Furthermore, there is a common conviction that if the economy is to attain sustainable growth in employment it must rely heavily on its smaller firms (AL-Hyari et al., 2012). Since the manufacturing sector is composed mainly of SMEs, and makes a significant contribution to Jordan's economy, then a specialised study that investigates the barriers for this sector is needed.

As a result of the vulnerability of the Middle East area and as an outcome of the recent developments in Iraq and Syria, the unstable security presented a devastating blow to Jordan's economy, particularly to the SME sector, leading to a substantial increase in unemployment (AL-Hyari et al., 2011). Also, the global financial and economic crisis presents significant challenges for Jordan economy. Currently, SMEs in Jordan are facing serious challenges deriving from the crisis, and are suffering the effects of a contraction in both global and domestic markets. The global financial crisis generated negative effects not only on the bank sector, but also made economy rapidly fall into recession.

The risk that further rising unemployment causes to political steadiness is obvious, and hence it becomes clearer the importance of SMEs as a means of reducing this problem. Therefore, Jordan has to reassess its situation and provide transitional assistance to SMEs in order to continue and improve their function as the backbone of Jordan's economy. These facts raise the question, what is the exact barrier for Jordanian SMEs resulting to inability to compete in both local and international market. Consequently, recognizing and measuring the impact of these barriers is crucial for developing policies oriented toward creating growing SMEs with higher potential for employment and income generation.

\section{Research Methodology}

The purpose of this research is descriptive, which concerned with identifying and counting the frequency of a specific population and create a picture of a situation objectively. In this research the author aims to describe the main barriers that facing SMEs in Jordan. This research obtained through the questionnaires that consist of particular barrier reasons of SMEs. To analyse the barriers facing SMEs owners, respondents were asked to measure the extent to which they experience barriers regarding the variables listed in Table 1 above. These barriers have been drawn from the most frequently referred list of barriers as Table 1 illustrates.

The delivery and collection questionnaire has been selected as the most appropriate survey instrument. The questionnaire asked managers to rank the importance of 15 potential barriers to SMEs development, using a 1-5 Likert scale $(1=$ not important and $5=$ very important $)$. In the Likert scale adopted, the value ' 3 ' is considered as the neither 'agree' nor 'disagree' status. It means that value greater than ' 3 ' is considered that variables act as a barrier for SME development. Similarly, if mean value is less than ' 3 ' it is considered that that variable is not a barrier for the development of SME. Based on the results obtained for variable mean values, descriptive statistics were computed and Table 2 shows the results.

The sample was drawn from the population of Jordanian industrial firms that were determined based on the Jordanian ministry of industry and trade as definition of small and medium sized organisations employing 249 
personnel or fewer (Al-Hyari et al., 2012). The questionnaire was piloted with a small group of respondents and some academic in relevant disciplines to test face validity for the designed questions. Cronbach's Alpha was used to test the reliability of the measurement scales. The results of the analysis revealed a Cronbach's alpha coefficient was greater than $80 \%$ shows that questionnaire is reliability.

\section{Analysis Results and Discussion}

A total of 246 questionnaires were returned from 400 questionnaires, 241 of which were useable. This translates into an overall response rate of 61.50 per cent, and usable response rate of 60.25 per cent.

According to the mean value of the importance distribution of Jordanian SMEs' perception towards barriers considered by way of their work. Table 2 shows that the most important perceived barriers for SMEs development seem to be: High cost of financing, low access to credit facilities, lack of qualified human resources, and the competition difficulties ranked very high. Rigid business rules and regulations, lack of government, and lack of information technology support are another area of concern.

Finance is one of the common problems facing all SMEs in Jordan. This can be observed in the firms need for funds to start-up and grow. The banking sector is reluctant to lend to SMEs since they are unable to pledge enough collateral so they need more soft loans with simple requirements of SMEs credit scheme applications (Al-Hyari et al., 2012).

According to Okpara and Kabongo (2009) it is recommended that small business owners should source cheap, low interest loans from banks and other financial institutions, and seek loans from micro financing organizations. It is important to provide funding support on soft terms without any complicated paper procedures. It is recommended that the government should increase its involvement to encourage the financial institutes and banks to provide suitable credit facilities to this sector. The establishment of new commercial and contractual laws, property rights laws, real estate regulations and labor laws were all conducive to business relationships and facilitated access to external finance and the government grants or other forms of support may mitigate the effects of the private market's failure (Krasiqi, 2007; Maeseneire \& Claeys, 2012).

Table 2. Perceived potential barriers for SMEs development-mean

\begin{tabular}{lcc}
\hline Potential Barriers & Mean Value & Rank \\
\hline E-Learning implementation & 4.01 & 15 \\
Lack of information technology & 4.27 & 7 \\
High cost of financing & 4.45 & 1 \\
Lack of HR/Personnel training & 4.41 & 2 \\
Competition difficulties & 4.36 & 4 \\
Product and process technology management & 4.25 & 8 \\
barriers & & \\
Rigid business rules and regulations & 4.32 & 5 \\
lack of infrastructure & 4.19 & 11 \\
Product quality issues & 4.20 & 10 \\
Low access to credit facilities & 4.39 & 3 \\
Geographical location & 4.7 & 14 \\
Inappropriate marketing strategy & 4.21 & 9 \\
Corruption & 4.13 & 13 \\
Lack of management experience & 4.17 & 12 \\
Lack of government support & 4.30 & 6 \\
\hline
\end{tabular}

Problems related to human resources may arise because of lack of particular knowledge and know-how to deal with such business tasks. This can be attributed to insufficient training of company workers in business issues. SMEs also admitted that they lack in reliable and skilful employees due to lack of education and training related to the business. According to Irjayanti and Azis, (2012) and Okpara and Kabongo (2009) management workshops and seminars can be organized by local chambers of commerce, universities, and other non-profit organizations in order to provide owners with the fundamental skills in management to manage their businesses on a daily basis. Saini and Budhwar, (2008) recommend that, if SMEs want to shift their focus from the cost-minimization and profits maximization approach to brand-building and faster growth model of business, they would have to tackle people issues more professionally. Also, universities and technical 
institutions should open doors to SMEs, adopt clusters and provide appropriate technologies, and provide training facilities to SMEs. Attracting entrepreneurial people to the SME sector needs to be initiated from school. There is a need to introduce entrepreneurship programs in the school curriculum at an early stage (Dasanayaka et al., 2011; Xie et al., 2011).

Table 2 shows that SMEs consider their main barriers for selling locally and abroad to be the instability in markets and strict rules and regulations. The findings show that the vast majority of the manufacturing SMEs in Jordan that see certain political and economic uncertainly in both home and foreign markets tend to make them difficult to make predictions for future business development, and highly bureaucratic business environments lead to generates cost.

SMEs argued that strong competition is a big problem to be faced today, not only to compete with other SME products, but also with large-scale enterprises. SMEs lack of competitiveness is due to their high relative unit cost and lack of human skills and knowledge, which prevent them from being competitive. Domestic markets are no longer the preserve of indigenous firms as the latter are under attack from overseas markets. Also, the market is fulfilled with many competitors with more strength which made it difficult for them to compete and is related to the political instability of the region particularly in Iraq and Palestine, and the lower in Jordan's competitors' prices owing to the recessionary conditions in world economy and sluggishness in world trade.

It is evidently the case that the prospects for future growth in Jordan's manufacturing depend on competitive products that can face the challenges in the rapidly changing external environment and can succeed in penetrating new markets and in increasing market shares. Government policies that encourage and support innovation among all firms, especially small firms, can help countries remain competitive in a global market. Public policy that encourages innovation can enable firms to remain competitive and survive (Guijarro et al., 2009). Moy and Luk (2003) suggest that to compete, firms need to innovate and observe market trends and consumer likings closely.

SMEs that consider lack of information an important barrier, show high probabilities of having a poor performance and can play a strong role in their failure. Government should adopt programs to protect the information to prevent misuse and to increase internet security. Also develop a political vision, and design mechanisms for the cooperation between parties to control e-services, regardless type of service. In addition, the government should focus on improving technical infrastructure necessary for the operation of e-commerce and the procedures and internal systems support e-commerce. Finally, government should improve the legal infrastructure such as privacy law, e-signature and knowledge acquisition law. According to Xie et al., (2010), policy makers should place greater emphasis on using market and information instruments to engage firms in innovation activities, create mechanisms to facilitate local cooperation network for SMEs and access information about new technology and tacit knowledge.

In developed countries, technology is an important source of competitive advance over local producers but in less developed countries other sources of competitive advantage, for example low costs could be more important. According to Irjayanti and Azis, (2012) SMEs are unable to adopt technology which can help them produce more efficient in time and cost since SMEs could not afford the price of technology, which put them behind their competitor in global market. Government should facilitate SME with technology through soft loan to buy supporting technology for their business. Furthermore, there is a need to reduce costs, and to this end, it is recommended that existing production and operation methods be changed by more contemporary techniques.

\section{Conclusions and Recommendations}

To understand barriers that face SMEs development and undertake efficient assistance, a close cooperation between the government, its promotional institutions, the business community, and the private sector is essential. Consequently, administrations in Jordan need to be trained in the skills of their counterparts in developed countries.

This study has provided a contribution to the literature by discussing the empirical findings and formulation conclusions from a Jordanian perspective and therefore has laid the foundations for researchers to replicate the research in other countries, in addition to advancing particular aspects of this study in Jordan. Therefore, it is an initial step for future research and needs more research for validation.

Based on these results, the following recommendations may contribute to increasing the role of the development of SMEs sector in Jordan. These recommendations are as follows:

1) Establish more centers that increase the awareness in SMEs in the manufacturing sector to be more trained about how to deal with SMEs barriers and addressing the shortage of people with the skills to advise SMEs 
on the best solutions for these barriers.

2) Have more support through non-bank lending routes to support people with a proposition that looks viable but who lack sufficient resources to start up and cannot attract bank finance. Providing funding support on soft terms without any complicated paper procedures. Financial incentives might include low-interest loans, transport subsidies and tax relief.

3) Implement the comprehensive program for exemption industrial inputs from custom duties. Tax reliefs especially at the initial stage of the SME, help in exports, up-gradation of skills in management are other initiatives in this direction.

4) The use of e-commerce as a tool for overcoming distance to markets at minimal costs, to present the products or services that they wish to offer to customers.

5) Reduce the costs of making business in Jordan by encouraging technology development through technology transfer or technological innovations. The universities and technical institutions should open doors to SMEs, adopt clusters and provide training facilities to SMEs. There is a need to introduce entrepreneurship programs in the school curriculum at an early stage to reduce the difficulties faced by innovative entrepreneurship.

\section{Limitations and Future Research}

The evidence reported in this study should be interpreted in the light of several limitations. Notably, with such a limited number of questions, it is not possible to fully evaluate the origin of a given barrier, nor to test the implications of a barrier on another. Also, this study effort was limited to manufacturing companies of a certain industrial sector within a specific small country context, thus caution is to be exercised when generalising the present findings.

Not all the barriers that may affect SMEs growth in Jordan were examined, and there might be other factors. Therefore, it is beneficial for future research to explore other factors. Another limitation is that, the data obtained related to a very specific period and therefore, longitudinal studies are recommended. Again, enlarging the number of questions and the sample investigated seems the preferred means in order to obtain the needed information to provide consistent and statistically based conclusions.

Despite its limitations, this study furthers our understanding of SME growth and its major barriers. The results present useful information for SMEs to better understand and be prepared for these barriers. In conclusion, the finding of this study contribute to the literature on SME studies and suggest directions for further research on issues relating to the growth and development of SMEs in developing countries and in particular, Jordan.

\section{References}

Ajlouni, K. (2006). The Financing Problems of Small and Medium-Sized Manufacturing Enterprises in Jordan. Durham University. Unpublished PhD.

Al-Hyari, K., \& Alnsour, M. (2012), Barriers to internationalisation in SMEs: evidence from Jordan. Marketing Intelligence and Planning, 30(2), 188-211. http://dx.doi.org/10.1108/02634501211211975

Al-Hyari, K., Al-Nasour, M., Al-Weshah, G., \& Abutayeh, B. (2011). Exporting Performance and Manufacturing Activities in Jordanian SMEs: External Barriers and Relationships. International Journal of Global Business, 4(1), 44-72.

Bourletidis, K. (2013). The strategic management of market information to SMEs during economic crisis. Procedia-Social and Behavioural Sciences, 73, 598-606. http://dx.doi.org/10.1016/j.sbspro.2013.02.096

Dasanayaka, S., Kankanamge, R., \& Sardana, G. (2011). Identification of Barriers for Development of the Sri Lankan Small and Medium Scale Furniture and Wooden Products Manufacturing Enterprises. Euro Asia Journal of Management, 21(40), 69-101.

DOS. (2011). Jordan in Figures. Amman: Department of Statistics. (In Arabic).

Feldens, M., Maccari, E., \& Garcez, M. (2012). Barriers for production innovation in small and medium technology-based firms in Brazil. Brazilian Business Review, 9(3), 1-12.

Guijarro, A., Garcia, M., \& Auken, H. (2009). Barriers to Innovation among Spanish Manufacturing SMEs. Journal of Small Business Management, 47(4), 465-488. http://dx.doi.org/10.1111/j.1540-627X.2009.00279.x

Gunerergin, M., Penbek, S., \& Zaptcioglu, D. (2012). Exploring the Problems and Advantages of Turkish SMEs 
for Sustainability. Procedia - Social and Behavioral Sciences, 58, 244-251.

Hessels, J., \& Parker, S. (2013). Constraints, internationalization and growth: A cross-country analysis of European SMEs. Journal of World Business, 48(1), 137-148. http://dx.doi.org/10.1016/j.jwb.2012.06.014

Hyz, A. B. (2011). Small and Medium Enterprises (SMEs) in Greece - Barriers in Access to Banking Services. An Empirical Investigation. International Journal of Business and Social Science, 2(2), 161-165.

Irwin, D., \& Scott, J. (2010). Barriers faced by SMEs in raising bank finance. International Journal of Entrepreneurial Behaviour \& Research, 16(3), 245-259.

Irjayanti, M., \& Azis, A. (2012). Barrier Factors and Potential Solutions for Indonesian SMEs. Procedia Economics and Finance, 4, 3-12. http://dx.doi.org/10.1108/13552551011042816

Janita, I., \& Chong, W. (2013). Barriers of B2B e-Business Adoption in Indonesian SMEs: A Literature Analysis. Procedia Computer Science, 17, 571-578. http://dx.doi.org/10.1016/S2212-5671(12)00315-2

Kamalian, A., Rashki, M., \& Arbabi, M. (2011). Barriers to Innovation among Iranian SMEs. Asian Journal of Business Management, 3(2), 79-90. http://dx.doi.org/10.1016/j.procs.2013.05.073

Krasiqi, B. (2007). Barriers to Entrepreneurship and SME Growth in Transition: the Case of Kosova. Journal of Developmental Entrepreneurship, 12(1), 71-94. http://dx.doi.org/10.1142/S1084946707000563

Leonidou, L. (2004). An Analysis of the Barriers Hindering Small Business Export Development. Journal of Small Business Management, 42(3), 279-302. http://dx.doi.org/10.1111/j.1540-627X.2004.00112.x

Maeseneire, W., \& Claeys, T. (2012). SMEs, foreign direct investment and financial constraints: The case of Belgium. International Business Review, 21(3), 408-424. http://dx.doi.org/10.1016/j.ibusrev.2011.03.004

Medarova, V., Bures, V., \& Otcenaskova, T. (2012). A Review of Obstacles to Successful e-Learning Deployment in SMEs. Journal of Innovation Management in Small \& Medium Enterprises, 12, 1-9. http://dx.doi.org/10.5171/2012.715039

Moy, J., \& Luk, V. (2003), The Life Cycle Model as a Framework for Understanding Barriers to SME Growth in Hong Kong. Asia Pacific Business Review, 10(2), 199-220. http://dx.doi.org/10.1080/13602380410001677218

Mutalemwa, D. (2009). Barriers to SMEs Development in the Manufacturing Sector: Evidence from Tanzania. African Journal of Business and Economic Research, 4(2), 93-111.

Okpara, J., \& Kabongo, J. (2009). An Empirical Evaluation of Barriers Hindering the Growth of Small and Medium Sized Enterprises (SMEs) in a Developing Economy. African Journal of Business and Economic Research, 4(1), 7-21. http://dx.doi.org/10.1108/01409171111102786

Okpara, J. (2011). Factors constraining the growth and survival of SMEs in Nigeria Implications for poverty alleviation. Management Research Review, 34(2), 156-171.

Peci, F., Kutllovci, E., Tmava, Q., \& Shala, V. (2012). Small and Medium Enterprises Facing Institutional Barriers in Kosovo. International Journal of Marketing Studies, 4(1), 95-107. http://dx.doi.org/10.5539/ijms.v4n1p95

Quader, M. (2008). Human Resource Management Issues as Growth Barriers in Professional Service Firm SMEs. Journal of Services Research, 7(2), 115-161.

Rasheed, H. S. (2005). Foreign Entry Mode and Performance: The Moderating Effects of Environment. Journal of Small Business Management, 43(1), 41-54. http://dx.doi.org/10.1111/j.1540-627X.2004.00124.x

Rhaiem, M. (2012). Determinants of Export Effort in Innovative Manufacturing SMES: an Empirical Study. International Journal of Business Strategy, 12(3), 81-93.

Saixing, Z., Xie, X. M., Tam, C. M., \& Wan, T. W. (2009). Relationships between Business Factors and Performance in Internationalization: An Empirical Study in China. Management Decision, 47(2), 308-329. http://dx.doi.org/10.1108/00251740910938939

Saini, D., \& Budhwar, P. (2008). Managing the human resource in Indian SMEs: The role of indigenous realities. Journal of World Business, 43(4), 417-434. http://dx.doi.org/10.1016/j.jwb.2008.03.004

Siaw, C., \& Abdul, R. N. (2012). Critical Review on the Regulatory and Legislation Challenges Faced by Halal Start-up SMEs Food Manufacturers in Malaysia. Procedia-Social and Behavioural Sciences, 57, 541-548. http://dx.doi.org/10.1016/j.sbspro.2012.09.1222 
Simpson, M., Jo Padmore, N. T., \& Jane, B. H. (2006). Marketing in Small and Medium Sized Enterprises. International Journal of Entrepreneurial Behaviour \& Research, 12(6), 361-387. http://dx.doi.org/10.1108/13552550610710153

Trianni, A., \& Cagno, E. (2012). Dealing with barriers to energy efficiency and SMEs: Some empirical evidences. Energy, 37(1), 494-504. http://dx.doi.org/10.1016/j.energy.2011.11.005

Tesfom, G., \& Clemens, L. (2006). A Classification of Export Marketing Problems of Small and Medium Sized Manufacturing Firms in Developing Countries. International Journal of Emerging Markets, 1(3), 262-281. http://dx.doi.org/10.1108/17468800610674480

Tesfom, G., \& Clements, L. (2008). Evaluating the Effectiveness of Export Support Services in Developing Countries: A Customer (User) Perspective. International Journal of Emerging Markets, 3(4), 364-377. http://dx.doi.org/10.1108/17468800810906075

Wieneke, A., \& Gries, T. (2011). SME performance in transition economies: The financial regulation and firm-level corruption nexus. Journal of Comparative Economics, 39(2), 221-229. http://dx.doi.org/10.1016/j.jce.2010.09.001

Xie, X., Zeng, S., \& Tam, T. (2010). Overcoming barriers to innovation in SMEs in China: A perspective based cooperation network. Innovation: Management, Policy \& Practice, 12(3), 298-310. http://dx.doi.org/10.5172/impp.12.3.298

Zaied, A. N. (2012), Barriers to E-Commerce Adoption in Egyptian SMEs. Information Engineering and Electronic Business, 3, 9-18. http://dx.doi.org/10.5815/ijieeb.2012.03.02

\section{Copyrights}

Copyright for this article is retained by the author(s), with first publication rights granted to the journal.

This is an open-access article distributed under the terms and conditions of the Creative Commons Attribution license (http://creativecommons.org/licenses/by/3.0/). 